\title{
The Economic Impact Of Sports And Sporting Events On The Charlotte Metropolitan Statistical Area (MSA) Economy
}

John E. Connaughton, UNC Charlotte, USA Caroline Swartz, UNC Charlotte, USA

\begin{abstract}
The sports economy in the Charlotte MSA has grown dramatically in the past twenty-five years. In 1980, attendance was less than 500,000 and total revenue was less than \$15 million. In 2011, Charlotte hosted a National Basketball team, a National Football team, two major NASCAR Cup events, several college teams, and a number of other important events. This study calculated the economic impact of sports and sports events in the Charlotte MSA in 2011.
\end{abstract}

NAICS data cannot be readily recast to isolate the sports industry, so this study used primary and secondary data. The data were divided into four categories:

- Professional and College Sports Teams

- Special Events (PGA, NASCAR, etc.)

- Major Amateur and Youth Events (including TEAM Charlotte Swimming, BASS/ESPN Outdoors)

- Sports Video and Media Productions

Once data on the direct output from sporting activities are assembled, the IMPLAN 382 by 382 multiplier matrix was used to calculate the indirect effects and the induced effects of the sporting activities and the employment supported by the estimated economic activity.

In 2011, sports and sporting events contributed over $\$ 1$ billion directly to the regional economy and a total of more than $\$ 2$ billion when indirect and induced effects are considered. The direct effect amounts to 0.7 percent of the MSA GDP and the total effect is 1.7 percent. This economic contribution supports nearly 14,000 jobs directly and more than 23,000 when indirect and induced effects are taken into account. This corresponds to 0.6 percent and 0.8 percent of total employment, respectively.

Keywords: Charlotte; Sports Economics; Regional Economics; Economic Impact

\section{INTRODUCTION}

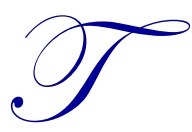

he Charlotte metropolitan economy has experienced dramatic growth in the last forty years, with per capita personal income increasing $963 \%$ over the period. Personal income in the Charlotte MSA grew from $\$ 2.7$ billion in 1970 to more than $\$ 69.2$ billion in 2010 . The metropolitan area population was 1.8 million in 2010, making Charlotte the nation's thirty-third largest MSA. The Charlotte MSA has consistently ranked among the nation's fasted growing MSAs, ranking behind only Las Vegas, Raleigh, and Austin in the past decade (US Department of Commerce, Bureau of Economic Analysis). 
In that same forty-year period, the sports sector in Charlotte has grown in size and diversity despite some early setbacks. The Charlotte Motor Speedway has hosted major events every year since 1960, gaining importance as NASCAR emerged as a major national sport. In 1969, Charlotte became home to the American Basketball Association's Cougars, though the team moved to St. Louis in 1974. The Charlotte Stars of the World Football League played two games in 1974 and seven home games in 1975 before the league folded. By the end of the 1970s, Charlotte seemed resigned to minor league team sports. Estimated attendance for all of 1980, shown in Table 1 , was less than a half million. Revenue figures from that period are not available, but an estimate based on published prices suggests the total ticket revenue was less than $\$ 6,000,000$. Total revenue, including concessions, parking, television, and radio, was less than $\$ 15,000,000$.

Table 1: Charlotte Sports, 1980

\begin{tabular}{lcc}
\hline \multicolumn{1}{c}{ Team/Event } & Sport & Attendance \\
\hline Charlotte Motor Speedway & NASCAR & 190,000 \\
Charlotte O's & AA Baseball & 190,000 \\
UNC Charlotte & NCAA Basketball & 40,000 \\
North/South Doubleheader & NCAA Basketball & 18,000 \\
Sun Belt Conference Tournament & NCAA Basketball & 10,000 \\
\hline Total & & 448,000 \\
\hline
\end{tabular}

Charlotte's sports profile changed when the National Basketball Association awarded a franchise to Charlotte. The Hornets began playing in 1998, leading the NBA in attendance and beginning a series of 358 consecutive sell-outs over a nine-year period. The success of the Hornets was followed by a National Football League franchise, the Panthers, in 1993. After playing the 1994 season in Clemson, South Carolina, the Panthers moved to their new stadium in downtown Charlotte in 1995 and began selling out the 72,000 seat stadium.

In the late 1990's, NASCAR began to emerge as a national sport with major U.S. corporate sponsorship. In December 1999, Fox and NBC signed a contract with NASCAR to televise every NASCAR Cup event live. This contract changed the economics of NASCAR racing and generated a major economic enhancement of the Charlotte motorsports industry, including the NASCAR teams and Charlotte Motor Speedway.

In 2011, attendance of sporting events exceeded 4.7 million, generating direct revenue (on-site and off-site) of more than $\$ 1$ billion and nearly 14,000 jobs. Total spending, including both direct and indirect revenues, was nearly $\$ 2.2$ billion and generated more than 23,000 jobs in the Charlotte MSA area.

Since 2011, there have been two significant developments. In UNC Charlotte's inaugural season of men's football team, 2013, all 15,000 seats are likely to be sold for each of the six home games. Preparations are underway for the relocation of the Charlotte Knights from their Fort Mill, South Carolina, home to the new 10,000 seat BB\&T Ballpark in downtown Charlotte in 2014. Preliminary estimates indicate that 600,000 fans will be drawn to the Knights' games in the inaugural season, further expanding the role of the sports sector in the Charlotte MSA economy.

\section{DATA COLLECTION AND ECONOMIC IMPACT METHODOLOGY}

The North American Industrial Classification System was designed to provide data on aggregate industryspecific groupings. Some industry clusters, such as sports entertainment and the video production and distribution industries are not comprised of homogeneous firms within a unique NAICS code. The sports industry is made up of professional sports teams in national leagues that engage in regularly-scheduled events at a single venue (NBA, NFL), traveling leagues that conduct events in different regions over the course of a season (NASCAR, PGA), and special one-time only events (Confederation of North, Central American and Caribbean Association Football Gold Cup). In addition to the professional events, there is an extensive range of regularly-scheduled college revenue sporting events (NCAA basketball and football), as well as special one-time college events (ACC Championship, CIAA tournament). In addition, the sports scene in Charlotte hosts numerous large amateur events that rotate through the region during the year. 
Finally, Charlotte is home to a recently developed sports video production and distribution industry. This is a group of firms classified in different NAICS codes based on the principal product they provide. Not all firms within each of these industry codes produce a product specifically related to the sports industry. As a result, there is no comprehensive secondary sports video production data source for output or employment.

\section{Data Collection and Sources}

Since NAICS data cannot be readily recast to isolate the sports industry, other primary and secondary data were used for this study. First, sports teams and sports video production firms were identified using information provided by the Charlotte Sports Commission. Firm and industry databases, such as Reference USA and Dunn \& Bradstreet, were used to collect the output and employment information for the firms' 2011 operations.

Second, an email survey was used to collect financial and employment information for each organization. This process ensures a more accurate assessment for each organization. Finally, discrepancies were resolved with a telephone interview.

Some entities, such as the Wells Fargo PGA Tournament, declined to participate in the survey because of concerns over proprietary data. In order to estimate the missing data for these organizations, averages based on responding organizations of similar size and activity were used. In some instances, there was no local similar event and so data and studies from other similar events in other cities of the same size as Charlotte were used.

The Charlotte Regional Visitors Authority has a catalog of every amateur sporting event staged in the Charlotte region during 2011. This data set includes both attendance and the spending behavior of attendees. Spending surveys were sent to over 2,500 ticket holders of various sporting events held in the Charlotte MSA during 2011. In addition, the Charlotte Regional Visitors Authority conducted numerous on-site surveys over the past several years for special sporting events and major amateur sports tournaments. Taken together, these two sources provide a picture of the distinct pattern of spending by sports fans while attending events in the Charlotte MSA.

This study aggregated data into the following four categories to portray meaningful industry sub-segments and to protect the privacy of proprietary data:

1. Professional and College Sports Teams: This category includes all the regularly scheduled major, minor, and college teams, including the Carolina Panthers, Charlotte Bobcats, Charlotte Knights, UNC Charlotte Men's basketball, and Johnson C. Smith University men's football and basketball.

2. Special Events: This category includes all the major professional and college sports events that occur on an occasional basis in the Charlotte region during the year. These events include both NASCAR and nonNASCAR races at Charlotte Motor Speedway, PGA Tournament, the ACC Football Championship, the Belk Bowl, the Gold Cup, and the CIAA Basketball Tournament.

3. Major Amateur and Youth Events: Approximately 150 major amateur and youth events were included in this study. Almost 140,000 players and fans attended these events. Most events were two days, but a few were as long as a week. Some of the many groups that organize such events include TEAM Charlotte Swimming, Charlotte Soccer Academy, Frank Glazier Football Clinics, BASS/ESPN Outdoors, and the North Carolina National Softball Association. In general, these events have no ticketing fee and little or no on-site spending. The economic impact of this category occurs off-site as a result of food and beverage spending and over-night accommodations.

4. Sports Video and Media Productions: This category includes firms that engage in the production of sportsrelated programming or distribution. This category includes ESPNU, SPEED, NASCAR Media Group, and Raycom Sports.

\section{METHODOLOGY}

This analysis uses output and employment as the measures of the economic impact of the sports industry. The first step is to calculate the direct output from sporting activities. Then the direct employment resulting from this level of output is calculated. The term "direct" refers to the dollar output or employment associated with the 
operation of the firm or industry being evaluated. For this study, direct effects are most closely associated with the total expenditures that take place while, or in association with, attending sporting events in the Charlotte MSA.

The indirect impacts measure the additional business and jobs created in non-sports industries that are supported by the direct economic activity of sports organizations and fan spending. These indirect effects are the supply-chain of a firm or organization. The induced impacts measure the additional business and jobs created in non-sports industries that are supported by the incomes of persons employed by sports organizations and by the supply-chain industries. Multipliers are used to translate the direct effects into indirect, induced, and total effects.

The Minnesota IMPLAN Group provides the basic multiplier data used in this study. The IMPLAN multipliers can apply to direct output and employment information to estimate the total impact of an industry on a region's economy. In addition, IMPLAN provides a comprehensive set of disaggregated multipliers that can estimate the indirect and induced impacts separately from the direct impact at the regional level.

This study used the IMPLAN 382 by 382 multiplier matrix for the Charlotte MSA to obtain multipliers for the dollar value of output and for employment numbers. This matrix provides multipliers for 382 detailed three- and four-digit NAICS industries. In addition, each of the 382 industries has an industry-specific indirect multiplier for itself and each of the other 381 industries. The multipliers are based on 2009 data, the most recent data available at the time of the study.

For this study, output and employment multipliers for the following IMPLAN sectors have been used:

- $\quad$ On-site spending: Spectator sports (403), Radio and television broadcasting (348), Cable networks and program distribution (349).

- $\quad$ Off-site spending: Retail stores - Food and beverage stores (324), Retail stores - Gasoline stations (326), Retail stores - General merchandise stores (329), Hotels and motels- including casino hotels (411), and Food services and drinking places (413).

Table 2 presents the output multipliers for the on-site revenue of Charlotte sports activities and the off-site revenue activity associated with attending sports activities. For example, each dollar of direct expenditure at sporting events (IMPLAN code 403) generates a total impact on economic output in the region of $\$ 2.04$. The total effect multipliers for the on-site spending categories range from $\$ 2.04$ to $\$ 2.29$.

Table 2 also includes the output multipliers for four industries associated with off-site expenditures in conjunction with attending sporting events in the Charlotte MSA. The interpretation of these output multipliers is the same as described above for on-site spending. Spending on Hotels and Motels has the largest impact with a multiplier of $\$ 1.89$. The smallest multiplier in the off-site spending category is Retail Services - General merchandise at $\$ 1.63$.

Table 2: 2011 IMPLAN Output Multipliers for the Charlotte MSA

\begin{tabular}{lclcccc}
\hline & $\begin{array}{c}\text { IMPLAN } \\
\text { Code }\end{array}$ & \multicolumn{1}{c}{ Description } & Direct & Indirect & Induced & Total \\
\hline \multirow{2}{*}{ On- } & 403 & Spectator sports companies & 1 & 0.382510 & 0.653353 & 2.035863 \\
site & 348 & Radio and television broadcasting & 1 & 0.555059 & 0.687118 & 2.242178 \\
& 349 & Cable networks and program distribution & 1 & 0.683081 & 0.609495 & 2.292575 \\
\hline & 324 & Retail Stores - Food and beverage & 1 & 0.175360 & 0.463989 & 1.639349 \\
Off- & 326 & Retail Stores - Gasoline stations & 1 & 0.188820 & 0.466854 & 1.655674 \\
site & 329 & Retail Stores - General merchandise & 1 & 0.170310 & 0.460843 & 1.631152 \\
& 411 & Hotels and motels, including casino hotels & 1 & 0.499457 & 0.391355 & 1.890812 \\
& 413 & Food services and drinking places & 1 & 0.402077 & 0.398271 & 1.800348 \\
\hline
\end{tabular}

Because many of the attendees at sporting events within the Charlotte MSA are local residents, an adjustment was made to their off-site spending to remove spending local residents would have done independent of the sporting event. The adjustment for the substitution effect is unique to each event, depending on the percent of attendees that are from the Charlotte MSA. This adjustment was made on an event-by-event basis. For some 
events, 90 percent of attendees reside within the Charlotte MSA; for other events, less than 10 percent reside in the MSA.

Table 3 presents the employment multipliers used to estimate the jobs impact of the on-site sports activities and the jobs impact of the off-site sports activities associated with attending sports activities during 2011. The multipliers listed in Table 3 show the number of jobs created for each $\$ 1,000,000$ of direct spending within each industry.

Table 3: 2011 IMPLAN Employment Multipliers for the Charlotte MSA

\begin{tabular}{lclcccc}
\hline & IMPLAN Code & \multicolumn{1}{c}{ Description } & Direct* & Indirect* & Induced* & Total* \\
\hline \multirow{2}{*}{ On- } & 403 & Spectator sports companies & 15.479735 & 4.068010 & 5.390037 & 24.937782 \\
Site & 348 & Radio and television broadcasting & 4.244166 & 4.934700 & 5.691076 & 14.869942 \\
& 349 & Cable networks and program distribution & 2.801979 & 4.653201 & 5.050521 & 12.505702 \\
\hline & 324 & Retail Stores - Food and beverage & 17.730496 & 1.308466 & 3.827030 & 22.865992 \\
\multirow{2}{*}{ Off- } & 326 & Retail Stores - Gasoline stations & 14.023308 & 1.406013 & 3.859733 & 19.289055 \\
Site & 329 & Retail Stores - General merchandise & 16.517691 & 1.275109 & 3.798328 & 21.591128 \\
& 411 & Hotels and motels, including casino hotels & 9.668748 & 3.681624 & 3.227083 & 16.577455 \\
& 413 & Food services and drinking places & 16.591027 & 2.727321 & 3.283219 & 22.601568 \\
\hline
\end{tabular}

* Jobs per $\$ 1,000,000$ of output

\section{ANALYSIS AND FINDINGS}

\section{Economic Impact of Professional and College Sports Teams}

The professional teams include the Charlotte Bobcats, Carolina Panthers, Charlotte Checkers, Charlotte Knights, Kannapolis Intimidators, Charlotte Eagles, Carolina Speed, Charlotte Speed Demons, and Gastonia Grizzlies. The college teams include UNC Charlotte men's basketball, Davidson College football and men's basketball, Winthrop University men's basketball, Johnson C. Smith University football and men's basketball, Queens University men's basketball, and Wingate University football and men's basketball.

In this category, off-site numbers include spending by visiting teams, visiting officials, and visiting scouts. The substitution effect adjustment used the percentage of fans that attend events from outside the MSA, which ranged from 10 to 40 percent in this category. The spending by fans from inside the MSA is reduced by 50 percent.

Table 4 presents the output impact of the professional and college teams on the Charlotte MSA economy. The on-site revenue consists of 100 percent of all revenue reported by the individual teams. It includes all ticket, luxury box, club seat, concession, novelty, parking, national TV, local TV, naming rights, royalty rights, advertising, and game promotion revenues.

The direct spending in 2011 in this category was $\$ 402,358,507$, divided as $\$ 344,168,705$ direct on-site revenue and $\$ 58,189,802$ direct off-site revenue. When indirect and induced spending is included, the total revenue in this category was $\$ 800,656,740$, of which $\$ 700,687,377$ was on-site revenue and $\$ 99,656,740$ was off-site revenue.

Table 4: Output Impact of Professional and College Sports Teams

\begin{tabular}{lcccc}
\hline \multicolumn{1}{c}{ Type (millions of dollars) } & Direct & Indirect & Induced & Total \\
\hline On-Site Revenue & $\$ 344.2$ & $\$ 131.6$ & $\$ 224.9$ & $\$ 700.7$ \\
Off-Site Revenue & $\$ 12.9$ & $\$ 2.3$ & $\$ 6.0$ & $\$ 21.2$ \\
$\quad$ Retail Stores - Food and beverage & $\$ 10.5$ & $\$ 2.0$ & $\$ 4.9$ & $\$ 17.4$ \\
$\quad$ Retail Stores - Gasoline stations & $\$ 9.6$ & $\$ 1.6$ & $\$ 4.4$ & $\$ 15.7$ \\
$\quad$ Retail Stores - General merchandise & $\$ 4.9$ & $\$ 2.4$ & $\$ 1.9$ & $\$ 9.3$ \\
$\quad$ Hotels and motels, including casino hotels & $\$ 20.3$ & $\$ 8.1$ & $\$ 8.1$ & $\$ 36.5$ \\
$\quad$ Food services and drinking places & $\$ 58.2$ & $\$ 16.5$ & $\$ 25.3$ & $\$ 100.0$ \\
\hline Total Off-Site Revenue & $\$ 402.4$ & $\$ 148.1$ & $\$ 250.2$ & $\$ 800.7$ \\
\hline Total Revenue & & &
\end{tabular}


Table 5 presents the employment impact of the professional and college sports teams for 2011. The direct employment from on-site activities is 5,328 jobs. This combines with the direct employment impact for off-site activities of 919 jobs to create a total direct employment impact of 6,246 jobs. The total employment impact from on-site activities is 8,583 jobs and the total employment impact for off-site activities is 1,245 jobs, making the total employment impact 9,827 jobs.

Table 5: Employment Impact of Professional and College Sports Teams

\begin{tabular}{lcccc}
\hline \multicolumn{1}{c}{ Type (number of jobs) } & Direct & Indirect & Induced & Total \\
\hline On-Site Employment & 5,328 & 1,400 & 1,855 & 8,583 \\
Off-Site Employment & & & & \\
Retail Stores - Food and beverage & 229 & 17 & 49 & 295 \\
Retail Stores - Gasoline stations & 147 & 15 & 41 & 203 \\
Retail Stores - General merchandise & 159 & 12 & 37 & 208 \\
Hotels and motels, including casino hotels & 47 & 18 & 16 & 81 \\
$\quad$ Food services and drinking places & 336 & 55 & 66 & 458 \\
Total Off-Site Employment & 919 & 117 & 209 & 1,245 \\
\hline Total Employment & 6,246 & 1,517 & 2,064 & 9,827 \\
\hline
\end{tabular}

The IMPLAN methodology identifies the most important in the supply-chain industries for professional and college sports. Tables 6 and 7 present the ten largest supply-chain IMPLAN industries measured by indirect impact levels for output and employment. These tables include the induced impacts of this supply chain activity and the total impact of the supply chain.

Table 6 shows that the industry with the largest supply-chain impact on output is Real estate establishments with $\$ 9,232,146$ in annual production. Three other industries (Management of companies and enterprises, Promoters of performing arts and sports and agents for public figures, and Insurance carriers) each provide the professional and college sports sector over $\$ 5,000,000$ in production annually.

When considering the total economic impact, five industries contribute more than $\$ 10$ million each: real estate establishments, promoters of performing arts and sports and agents for public figures, telecommunications, nondepository credit intermediation and related activities, and wholesale trade businesses.

Table 6: Output in the Supply-Chain Industries

\begin{tabular}{lccc}
\hline \multicolumn{1}{c}{ Industry (millions of dollars) } & Indirect & Induced & Total \\
\hline Real estate establishments & $\$ 9.2$ & $\$ 18.1$ & $\$ 27.3$ \\
Management of companies and enterprises & $\$ 7.4$ & $\$ 2.2$ & $\$ 9.6$ \\
Promoters of performing arts and sports and agents for public figures & $\$ 5.9$ & $\$ 0.6$ & $\$ 6.5$ \\
Insurance carriers & $\$ 5.1$ & $\$ 11.4$ & $\$ 16.5$ \\
Radio and television broadcasting & $\$ 4.5$ & $\$ 1.1$ & $\$ 5.6$ \\
Telecommunications & $\$ 4.5$ & $\$ 6.0$ & $\$ 10.5$ \\
Nondepository credit intermediation and related activities & $\$ 3.4$ & $\$ 8.5$ & $\$ 11.9$ \\
Wholesale trade businesses & $\$ 3.2$ & $\$ 12.7$ & $\$ 15.9$ \\
Electric power generation, transmission, and distribution & $\$ 3.1$ & $\$ 4.6$ & $\$ 7.7$ \\
Management, scientific, and technical consulting services & $\$ 2.9$ & $\$ 1.6$ & $\$ 4.4$ \\
Industries 11 - 20 & $\$ 21.4$ & $\$ 25.4$ & $\$ 46.8$ \\
All other industries & $\$ 77.5$ & $\$ 158.2$ & $\$ 638.1 *$ \\
\hline Total & $\$ 148.1$ & $\$ 250.2$ & $\$ 800.7$ \\
\hline
\end{tabular}

* Includes direct effects of on-site and off-site spending.

Table 7 shows the jobs impact of the professional and college sports sector corresponding to the output data in Table 6. The industry with the largest supply-chain employment impact is promoters of performing arts and sports and agents for public figures which supports 114 jobs indirectly and a total of 125 jobs. Four other industries (real estate establishments, employment services, services to buildings and dwellings, and management of companies and enterprises) all support more than 30 indirect jobs as a result of annual spending by the professional and college team sector. 
Table 7: Employment in the Supply Chain Industries

\begin{tabular}{|c|c|c|c|}
\hline $\begin{array}{ll}\text { Industry (number of jobs) } \\
\end{array}$ & Indirect & Induced & Total \\
\hline Promoters of performing arts and sports and agents for public figures & 114 & 11 & 125 \\
\hline Real estate establishments & 81 & 158 & 239 \\
\hline Employment services & 47 & 34 & 81 \\
\hline Services to buildings and dwellings & 35 & 34 & 69 \\
\hline Management of companies and enterprises & 32 & 9 & 41 \\
\hline Accounting, tax preparation, bookkeeping, and payroll services & 26 & 15 & 42 \\
\hline Management, scientific, and technical consulting services & 23 & 13 & 35 \\
\hline Advertising and related services & 23 & 5 & 28 \\
\hline Radio and television broadcasting & 19 & 5 & 24 \\
\hline Insurance carriers & 17 & 38 & 56 \\
\hline Industries $11-20$ & 127 & 159 & 286 \\
\hline All other industries & 973 & 1,582 & $8,801 *$ \\
\hline Total & 1,517 & 2,064 & 9,827 \\
\hline
\end{tabular}

\section{Economic Impact of Special Events}

Special sporting events include races and other events at Charlotte Motor Speedway, zMAX Dragway, and the Dirt Track at Charlotte Motor Speedway, along with associated racing events like the Speed Street, a street fair in uptown Charlotte in association with the Charlotte Coca-Cola 600 NASCAR race in May. The special events category also includes all tournaments and one-time games from 2011 such as the Belk Bowl, ACC Championship game, the CIAA Tournament, NCAA Regionals, East Carolina University versus UNC Chapel Hill football game, Gold Cup International Soccer, and the PGA Tournament.

Table 8 provides the output impact of these special events on the Charlotte MSA economy. The on-site revenue consists of all revenue reported by the individual events, including ticket, luxury box, club seat, concession, novelty, parking, national TV, local TV, naming rights, royalty rights, advertising, and game promotion revenues. The off-site spending calculations use the same methodology described for the Professional and College Sports Teams category.

Table 8: Output Impact of Special Sports Events

\begin{tabular}{lcccc}
\hline \multicolumn{1}{c}{ Type (millions of dollars) } & Direct & Indirect & Induced & Total \\
\hline $\begin{array}{l}\text { On-Site Revenue } \\
\text { Off-Site Revenue }\end{array}$ & $\$ 181.6$ & $\$ 69.4$ & $\$ 118.6$ & \\
$\quad$ & & & & \\
$\quad$ Retail Stores - Food and beverage & $\$ 20.3$ & $\$ 3.6$ & $\$ 9.4$ & $\$ 33.4$ \\
$\quad$ Retail Stores - Gasoline stations & $\$ 24.6$ & $\$ 4.7$ & $\$ 11.5$ & $\$ 40.8$ \\
$\quad$ Retail Stores - General merchandise & $\$ 21.9$ & $\$ 3.7$ & $\$ 10.1$ & $\$ 35.8$ \\
$\quad$ Hotels and motels, including casino hotels & $\$ 36.3$ & $\$ 18.1$ & $\$ 14.2$ & $\$ 68.7$ \\
$\quad$ Food services and drinking places & $\$ 36.8$ & $\$ 14.8$ & $\$ 14.7$ & $\$ 66.3$ \\
Total Off-Site Revenue & $\$ 140.1$ & $\$ 44.9$ & $\$ 59.9$ & $\$ 244.9$ \\
\hline Total Revenue & $\$ 321.6$ & $\$ 114.4$ & $\$ 178.6$ & $\$ 614.6$ \\
\hline
\end{tabular}

The total on-site revenue for all special events in 2011 was $\$ 321,638,306$, split between $\$ 181,562,247$ direct on-site and $\$ 140,076,059$ direct off-site revenues. The total output impact of special events was $\$ 614,555,979$, divided between $\$ 369,635,885$ on-site and $\$ 244,920,095$ off-site.

Table 9 presents the employment impact of special events for 2011. The direct employment impact from on-site activities is 2,811 jobs. This is combined with the employment impact for off-site activities of 2,031 for a direct employment impact of 4,841 jobs. The total employment impact from on-site activities is 4,528 jobs. This total, added to the 2,849 jobs supported by total offsite activities, produced a total employment impact of 7,376 jobs. 
Table 9: Employment Impact of Special Sports Events

\begin{tabular}{lcccc}
\hline \multicolumn{1}{c}{ Type (number of jobs) } & Direct & Indirect & Induced & Total \\
\hline On-Site Employment & 2,811 & 739 & & 979 \\
Off-Site Employment & & & 4,528 \\
$\quad$ Retail Stores - Food and beverage & 361 & 27 & 78 & \\
$\quad$ Retail Stores - Gasoline stations & 345 & 35 & 465 \\
$\quad$ Retail Stores - General merchandise & 362 & 28 & 95 & 475 \\
$\quad$ Hotels and motels, including casino hotels & 351 & 134 & 83 & 474 \\
$\quad$ Food services and drinking places & 611 & 100 & 121 & 602 \\
Total Off-Site Employment & 2,031 & 323 & 494 & 2,849 \\
\hline Total Employment & 4,841 & 1,062 & 1,473 & 7,376 \\
\hline
\end{tabular}

The effect of sports on the supply-chain industries is calculated in the same manner as in the section on Professional and College Sports Teams above. Tables 10 and 11 present the indirect, induced, and total impacts of the supply-chain IMPLAN industries measured by indirect impact levels for output and employment.

Table 10: Output Ranked by the Supply-Chain Industries

\begin{tabular}{|c|c|c|c|}
\hline Industry (millions of dollars) & Indirect & Induced & Total \\
\hline Real estate establishments & $\$ 9.4$ & $\$ 12.9$ & $\$ 22.3$ \\
\hline Management of companies and enterprises & $\$ 6.0$ & $\$ 1.5$ & $\$ 7.5$ \\
\hline Insurance carriers & $\$ 4.2$ & $\$ 8.1$ & $\$ 12.4$ \\
\hline Telecommunications & $\$ 4.1$ & $\$ 4.3$ & $\$ 8.4$ \\
\hline Electric power generation, transmission, and distribution & $\$ 3.9$ & $\$ 3.3$ & $\$ 7.2$ \\
\hline Radio and television broadcasting & $\$ 3.7$ & $\$ 0.8$ & $\$ 4.5$ \\
\hline Wholesale trade businesses & $\$ 3.5$ & $\$ 9.0$ & $\$ 12.5$ \\
\hline Promoters of performing arts and sports and agents for public figures & $\$ 3.2$ & $\$ 0.4$ & $\$ 3.6$ \\
\hline Nondepository credit intermediation and related activities & $\$ 2.8$ & $\$ 6.1$ & $\$ 8.8$ \\
\hline Management, scientific, and technical consulting services & $\$ 2.4$ & $\$ 1.1$ & $\$ 3.5$ \\
\hline Industries $11-20$ & $\$ 17.8$ & $\$ 16.4$ & $\$ 34.3$ \\
\hline All other industries & $\$ 53.4$ & $\$ 114.6$ & $\$ 489.6 *$ \\
\hline Total & $\$ 114.4$ & $\$ 178.6$ & $\$ 614.6$ \\
\hline
\end{tabular}

* Includes direct effects of on-site and off-site spending.

Table 10 shows that the industry with the largest supply-chain output impact is real estate establishments. This industry provides the special sporting events industry with $\$ 9,403,138$ in annual production. Three other industries (management of companies and enterprises, insurance carriers, and telecommunications) each provide the special events sector with over $\$ 4,000,000$ in production annually.

Table 11 shows employment corresponding to the output impacts in Table 10. The industry with the largest supply-chain employment impact is promoters of performing arts and sports and agents for public figures. This industry, because of both on-site and off-site spending, supports 61 jobs. Four other industries (employment services, services to buildings and dwellings, and management of companies and enterprises) each support more than 20 jobs.

Table 11: Employment Ranked by the Supply-Chain Industries

\begin{tabular}{lccc}
\hline \multicolumn{1}{c}{ Industry (number of jobs) } & Indirect & Induced & Total \\
\hline Promoters of performing arts and sports and agents for public figures & 61 & 8 & 69 \\
Employment services & 39 & 24 & 63 \\
Services to buildings and dwellings & 38 & 24 & 62 \\
Management of companies and enterprises & 26 & 7 & 32 \\
Accounting, tax preparation, bookkeeping, and payroll services & 21 & 11 & 32 \\
Management, scientific, and technical consulting services & 19 & 9 & 28 \\
Advertising and related services & 19 & 4 & 23 \\
Wholesale trade businesses & 17 & 44 & 61 \\
Radio and television broadcasting & 16 & 3 & 19 \\
Business support services & 14 & 9 & 23 \\
Industries 11 - 20 & 101 & 93 & 195 \\
All other industries & 691 & 1,237 & $6,768^{*}$ \\
\hline Total & 1,062 & 1,473 & 7,376 \\
\hline Includes direct on-site and off-site employment & & &
\end{tabular}




\section{Economic Impact of Major Amateur and Youth Events}

The impact of amateur and youth sporting events on the Charlotte MSA economy is the result of approximately 150 events and almost 140,000 players and fans during 2011. Some of the many groups that organize such events include TEAM Charlotte Swimming, Charlotte Soccer Academy, Frank Glazier Football Clinics, Carolina Scholastic Sports Association Inc., Top Gun Sports, Christian Cheerleaders of America, BASS/ESPN Outdoors, Palmetto Volleyball Association Inc., StickWithUs Lacrosse, Queen City Darting Association, and the North Carolina National Softball Association.

Table 12 provides the output impact of all the major amateur and youth events on the Charlotte MSA economy. There is no on-site revenue since most of these events do not charge admission, sell food, beverages, or promotional items. The off-site numbers include spending by fans (which include mostly family members of participants) in conjunction with attending events. Virtually all of the attendance is from outside the Charlotte region, so off-site spending is not adjusted to reflect the possible substitution effect. Off-site spending data are from fan surveys conducted by the Charlotte Regional Visitors Authority. The total off-site revenue for all major amateur and youth events in 2011 was $\$ 232,528,091$.

Table 12: Output Impact of Youth Sporting Events

\begin{tabular}{lcccc}
\hline \multicolumn{1}{c}{ Type (millions of dollars) } & Direct & Indirect & Induced & Total \\
\hline Off-Site Revenue & & & & \\
Retail Stores - Food and beverage & $\$ 20.0$ & $\$ 3.5$ & $\$ 9.3$ & $\$ 32.7$ \\
Retail Stores - Gasoline stations & $\$ 19.5$ & $\$ 3.7$ & $\$ 9.1$ & $\$ 32.3$ \\
Retail Stores - General merchandise & $\$ 21.5$ & $\$ 3.7$ & $\$ 9.9$ & $\$ 35.1$ \\
Hotels and motels, including casino hotels & $\$ 35.6$ & $\$ 17.8$ & $\$ 13.9$ & $\$ 67.4$ \\
$\quad$ Food services and drinking places & $\$ 36.1$ & $\$ 14.5$ & $\$ 14.4$ & $\$ 65.0$ \\
\hline Total Off-Site Revenue & $\$ 132.7$ & $\$ 43.2$ & $\$ 56.6$ & $\$ 232.5$ \\
\hline
\end{tabular}

Table 13 shows the employment impact of the amateur and youth events for 2011 . The total employment impact from off-site activities is 2,704 jobs.

Table 13: Employment Impact of Youth Sporting Events

\begin{tabular}{lcccc}
\hline Type (number of jobs) & Direct & Indirect & Induced & Total \\
\hline Off-Site Employment & & & & \\
Retail Stores - Food and beverage & 354 & 26 & 76 & 456 \\
Retail Stores - Gasoline stations & 273 & 27 & 75 & 376 \\
Retail Stores - General merchandise & 356 & 27 & 82 & 465 \\
Hotels and motels, including casino hotels & 345 & 131 & 115 & 591 \\
Food services and drinking places & 599 & 99 & 119 & 816 \\
\hline Total Off-Site Employment & 1,927 & 311 & 467 & 2,704 \\
\hline
\end{tabular}

Tables 14 and 15 present the ten largest supply-chain IMPLAN industries measured by indirect impact level for output and employment. These tables also identify the induced impacts of this supply chain activity and the total impact of the supply chain industries.

Table 14: Output Ranked by the Supply-Chain Industries

\begin{tabular}{lccc}
\hline \multicolumn{1}{c}{ Industry (millions of dollars) } & Indirect & Induced & Total \\
\hline Real estate establishments & $\$ 5.6$ & $\$ 4.1$ & $\$ 9.7$ \\
Electric power generation, transmission, and distribution & $\$ 2.7$ & $\$ 1.0$ & $\$ 3.7$ \\
Management of companies and enterprises & $\$ 2.5$ & $\$ 0.5$ & $\$ 2.9$ \\
Wholesale trade businesses & $\$ 2.3$ & $\$ 2.9$ & $\$ 5.2$ \\
Telecommunications & $\$ 2.0$ & $\$ 1.4$ & $\$ 3.4$ \\
Industries 6- 10 & $\$ 6.9$ & $\$ 7.6$ & $\$ 14.5$ \\
Industries 11 - 20 & $\$ 7.8$ & $\$ 3.4$ & $\$ 11.2$ \\
All other industries & $\$ 13.4$ & $\$ 35.8$ & $\$ 181.9 *$ \\
\hline Total & $\$ 43.2$ & $\$ 56.6$ & $\$ 232.5$ \\
\hline
\end{tabular}

* Includes direct on-site and off-site employment. 
Table 14 shows that the industry with the largest supply-chain output impact is real estate establishments followed by electric power generation, transmission, and distribution; management of companies and enterprises, and wholesale trade businesses.

Table 15 shows the largest supply chain employment impacts are from real estate establishments, services to buildings and dwellings, and employment services.

Table 15: Employment Ranked by the Supply-Chain Industries

\begin{tabular}{|c|c|c|c|}
\hline Industry (number of jobs) & Indirect & Induced & Total \\
\hline Real estate establishments & 49 & 36 & 85 \\
\hline Services to buildings and dwellings & 22 & 8 & 30 \\
\hline Employment services & 17 & 8 & 24 \\
\hline Wholesale trade businesses & 11 & 14 & 25 \\
\hline Management of companies and enterprises & 11 & 2 & 13 \\
\hline Industries $6-10$ & 40 & 11 & 51 \\
\hline Industries $11-20$ & 53 & 32 & 81 \\
\hline All other industries & 110 & 357 & $2,393 *$ \\
\hline Total & 311 & 467 & 2,704 \\
\hline
\end{tabular}

* Includes direct on-site and off-site employment.

\section{Economic Impact of Video and Media Production}

The impact of sports video and media production on the Charlotte MSA economy is calculated using data from ESPNU, NASCAR Media Productions, Raycom Sports, and SPEED. These video and media companies are not common in communities the size of Charlotte. Most of these types of organizations are located in traditional media cities such as New York, Los Angeles, and Nashville. However, the existence of the motorsports industry in the Charlotte metro area has developed this sports-oriented video and media cluster.

Table 16 provides the output and employment impacts of sports video and media production on the Charlotte MSA economy. The direct output for all sports video and media production in 2011 was $\$ 238,077,395$. The total revenue in 2011 was $\$ 540,466,828$. The direct employment impact was 820 jobs. The total employment impact of sports video and media production in 2011 was 3,228 jobs.

Table 16: Impact of Video Production and Media

\begin{tabular}{lcccc}
\hline \multicolumn{1}{c}{ Type } & Direct & Indirect & Induced & Total \\
\hline Output $(\$ \mathrm{M})$ & $\$ 238.1$ & $\$ 149.1$ & $\$ 153.3$ & $\$ 540.5$ \\
Employment (jobs) & 820 & 1,138 & 1,270 & 3,228 \\
\hline
\end{tabular}

The IMPLAN detailed multiplier methodology allows for the identification of the industries that are most important in the supply chain for sports video and media production. Tables 17 and 18 present the supply-chain IMPLAN industries measured by indirect impact levels for output and employment. These tables also identify the induced impacts of this supply chain activity and the total impact of the supply chain (indirect plus induced) on the Charlotte MSA for that industry.

Table 17 shows that the industry with the largest supply-chain output impact is spectator sports companies. This industry provides sports video and media production companies with $\$ 23,853,875$ in annual production. Three other industries (motion picture and video industries, real estate establishments, and telecommunications) each provide the sports video and media production sector over $\$ 4,000,000$ in production annually. 
Table 17: Output Ranked by the Supply-Chain Industries

\begin{tabular}{lccc}
\hline \multicolumn{1}{c}{ Industry (millions of dollars) } & Indirect & Induced & Total \\
\hline Spectator sports companies & $\$ 23.9$ & $\$ 0.4$ & $\$ 24.2$ \\
Motion picture and video industries & $\$ 11.7$ & $\$ 0.2$ & $\$ 11.9$ \\
Real estate establishments & $\$ 4.7$ & $\$ 10.6$ & $\$ 15.3$ \\
Telecommunications & $\$ 4.5$ & $\$ 3.6$ & $\$ 8.1$ \\
Lessors of nonfinancial intangible assets & $\$ 2.5$ & $\$ 0.2$ & $\$ 2.8$ \\
Industries 6 - 10 & $\$ 10.3$ & $\$ 17.1$ & $\$ 27.4$ \\
Industries 11 - 20 & $\$ 13.1$ & $\$ 35.6$ \\
All other industries & $\$ 78.5$ & $\$ 98.7$ & $\$ 415.2$ \\
\hline Total & $\$ 149.1$ & $\$ 153.3$ & $\$ 540.5$ \\
\hline
\end{tabular}

Table 18 shows the jobs impact on the sports video and media production sector. In this case, the industry with the largest supply chain employment impact is spectator sports companies. This industry supports 369 jobs. Motion picture and video industries supports 177 jobs, and both employment services and real estate establishments support more than 40 jobs each.

Table 18: Output Ranked by the Supply-Chain Industries

\begin{tabular}{lccc}
\hline \multicolumn{1}{c}{ Industry (number of jobs) } & Indirect & Induced & Total \\
\hline Spectator sports companies & 369 & 6 & 375 \\
Motion picture and video industries & 177 & 3 & 180 \\
Employment services & 46 & 21 & 67 \\
Real estate establishments & 41 & 93 & 134 \\
Services to buildings and dwellings & 20 & 21 & 41 \\
Industries 6 - 10 & 86 & 160 & 247 \\
Industries 11 - 20 & 88 & 110 & 197 \\
All other industries & 309 & 858 & 1,987 \\
\hline Total & 1,138 & 1,270 & 3,228 \\
\hline
\end{tabular}

\section{TOTAL ECONOMIC IMPACT OF THE SPORTS AND RELATED INDUSTRIES}

This section first considers the distribution of the economic impact of sports and related industries across all industries in the Charlotte Metropolitan region. The section shows the breakdown of output and employment impacts by their source using the four categories employed above. This section leads to a summary of the major findings of this research.

\section{Economic Impact by Type of Event}

Table 19 shows the output of the four sports categories studied. The greatest impact is made by Professional and College Teams, contributing about 36.8 percent to total direct output and 36.6 percent to total output. The strength of this sector helps support the three other categories by providing infrastructure, complementary services, and a growing brand as a sports region.

Special events contributes 29.4 percent of all direct output and 28.1 percent to total output. While Major Amateur and Youth Events are the smallest category, it contributes 12.1 percent to direct output and 10.6 percent to total output. Finally, the Sports Video and Media Production category accounts for 21.7 percent of direct output and 24.7 percent of total output.

Table 19: Output Summary by Category

\begin{tabular}{lcccccc}
\hline \multirow{2}{*}{ Segment (millions of dollars) } & \multicolumn{2}{c}{ Direct } & Indirect & Induced & \multicolumn{2}{c}{ Total } \\
\cline { 2 - 6 } & Output & Share & Output & Output & Output & Share \\
\hline Professional and College Teams & $\$ 402.4$ & $36.8 \%$ & $\$ 148.1$ & $\$ 250.2$ & $\$ 800.7$ & $36.6 \%$ \\
Special Events & $\$ 321.6$ & $29.4 \%$ & $\$ 114.4$ & $\$ 178.6$ & $\$ 614.6$ & $28.1 \%$ \\
Major Amateur and Youth Events & $\$ 132.7$ & $12.1 \%$ & $\$ 43.2$ & $\$ 56.6$ & $\$ 232.5$ & $10.6 \%$ \\
Sports Video and Media Production & $\$ 238.1$ & $21.7 \%$ & $\$ 149.1$ & $\$ 153.3$ & $\$ 540.5$ & $24.7 \%$ \\
\hline Total Revenue & $\$ 1,094.8$ & & $\$ 454.7$ & $\$ 638.7$ & $\$ 2,188.2$ \\
\hline
\end{tabular}


Table 20 shows the employment supported by the production attributable to sports and sporting events in the Charlotte Metropolitan region. Professional and College Teams account for 45.1 percent of direct employment and 42.5 percent of total employment. The Special Events category provides 35.0 percent of direct jobs and 31.9 percent of all jobs. Major Amateur and Youth Events employ 13.9 percent all direct jobs and 11.7 percent of all jobs.

Table 20: Employment Summary by Category

\begin{tabular}{lcccccc}
\hline \multirow{2}{*}{ Segment (Number of Jobs) } & \multicolumn{2}{c}{ Direct } & Indirect & Induced & \multicolumn{2}{c}{ Total } \\
\cline { 2 - 7 } & Jobs & Share & Jobs & Jobs & Jobs & Share \\
\hline Professional and College Teams & 6,246 & $45.1 \%$ & 1,517 & 2,064 & 9,827 & $42.5 \%$ \\
Special Events & 4,841 & $35.0 \%$ & 1,062 & 1,473 & 7,376 & $31.9 \%$ \\
Major Amateur and Youth Events & 1,927 & $13.9 \%$ & 311 & 467 & 2,704 & $11.7 \%$ \\
Sports Video and Media Production & 820 & $5.9 \%$ & 1,138 & 1,270 & 3,228 & $14.0 \%$ \\
\hline Total Employment & 13,834 & & 4,028 & 5,274 & 23,136 \\
\hline
\end{tabular}

\section{Analysis of Impact by Industry}

Table 21 provides the output impact of all sports and related industries on the Charlotte MSA economy for 2011. On-site spending accounts for 69.8 percent of all direct spending. Within the off-site direct revenue category, the three retail spending codes together accounted for 24.1 percent of the total output while hotels and motels, including casino hotels accounted for 7.0 percent of the total and food services and drinking places accounted for the remaining 8.5 percent. When total spending is considered, the on-site output accounts for 73.6 percent. The three retail categories together were 12.1 percent of total output. Hotels and motels, including casino hotels accounted for 6.6 percent of the total output and food services and drinking places accounted for the remaining 7.7 percent.

Half of the total impact is attributable to direct spending while indirect and induced spending represent 20.8 percent and 29.2 percent respectively.

Table 21: Output Summary by Industry

\begin{tabular}{lcccc}
\hline \multicolumn{1}{c}{ Type (millions of dollars) } & Direct & Indirect & Induced & Total \\
\hline On-Site Revenue & $\$ 763.8$ & $\$ 350.1$ & $\$ 496.8$ & $\$ 1,610.8$ \\
Off-Site Revenue & & & & \\
$\quad$ Retail Stores - Food and beverage & $\$ 53.2$ & $\$ 9.3$ & $\$ 24.7$ & $\$ 87.2$ \\
$\quad$ Retail Stores - Gasoline stations & $\$ 54.6$ & $\$ 10.3$ & $\$ 25.5$ & $\$ 90.4$ \\
$\quad$ Retail Stores - General merchandise & $\$ 53.1$ & $\$ 9.0$ & $\$ 24.5$ & $\$ 86.6$ \\
$\quad$ Hotels and motels, including casino hotels & $\$ 76.9$ & $\$ 38.4$ & $\$ 30.1$ & $\$ 145.3$ \\
$\quad$ Food services and drinking places & $\$ 93.2$ & $\$ 37.5$ & $\$ 37.1$ & $\$ 167.8$ \\
Total Off-Site Revenue & $\$ 331.0$ & $\$ 104.6$ & $\$ 141.9$ & $\$ 577.4$ \\
\hline Total Revenue & $\$ 1,094.8$ & $\$ 454.7$ & $\$ 638.7$ & $\$ 2,188.2$ \\
\hline
\end{tabular}

Table 22 presents the employment impact of all sports and related industries for 2011. On-site direct employment generates 64.8 percent of all direct employment. The three retail categories employ 18.7 percent and hotels and motels, including casino hotels employ 5.4 percent of all direct employment. The food services and drinking places share of total employment, 11.2 percent, is larger than its share of direct output because of the relatively high labor intensity of this industry.

When total employment is considered, on-site employment accounts for 70.6 percent of the total while the three retail categories are 14.8 percent of total employment. Hotels and motels, including casino hotels accounts for 5.5 percent of total employment; food services and drinking places are 9.1 percent of total employment.

Direct employment is 59.8 percent of total employment generated by the sports and related industries. Indirect employment is 17.4 percent of the total and induced employment is 22.8 percent. 
Table 22: Employment Summary by Industry

\begin{tabular}{lcccc}
\hline \multicolumn{1}{c}{ Type (number of jobs) } & Direct & Indirect & Induced & Total \\
\hline On-Site Employment & 8,958 & 3,276 & & 4,104 \\
Off-Site Employment & & & & 16,339 \\
$\quad$ Retail Stores - Food and beverage & 944 & 70 & 204 & 1,217 \\
$\quad$ Retail Stores - Gasoline stations & 766 & 77 & 211 & 1,053 \\
Retail Stores - General merchandise & 877 & 68 & 202 & 1,147 \\
Hotels and motels, including casino hotels & 743 & 283 & 248 & 1,274 \\
$\quad$ Food services and drinking places & 1,546 & 254 & 306 & 2,106 \\
Total Off-Site Employment & 4,876 & 751 & 1,170 & 6,798 \\
\hline Total Employment & 13,834 & 4,028 & 5,274 & 23,136 \\
\hline
\end{tabular}

Tables 23 and 24 present the largest supply chain industries measured by indirect impact level for output and employment. These tables also identify the induced impacts of this supply chain activity and the total impact of the supply chain. Table 21 shows that the industry with the largest supply chain output impact is real estate establishments. This industry provides sports and related industries with $\$ 28,964,658$ in annual production. Three other industries (management of companies and enterprises, telecommunications, and motion picture and video industries) all provide sports and related industries over $\$ 12,000,000$ each in production annually.

Table 23: Output Ranked by the Supply-Chain Industries

\begin{tabular}{lccc}
\hline \multicolumn{1}{c}{ Industry (millions of dollars) } & Indirect & Induced & Total \\
\hline Real estate establishments & $\$ 29.0$ & $\$ 45.7$ & $\$ 74.6$ \\
Management of companies and enterprises & $\$ 17.8$ & $\$ 5.5$ & $\$ 23.3$ \\
Telecommunications & $\$ 15.0$ & $\$ 15.3$ & $\$ 30.3$ \\
Motion picture and video industries & $\$ 12.6$ & $\$ 0.8$ & $\$ 13.4$ \\
Insurance carriers & $\$ 11.9$ & $\$ 29.2$ & $\$ 41.1$ \\
Wholesale trade businesses & $\$ 11.3$ & $\$ 32.1$ & $\$ 43.3$ \\
Electric power generation, transmission, and dist. & $\$ 10.7$ & $\$ 11.5$ & $\$ 22.2$ \\
Promoters of performing arts and sports and agents of public figures & $\$ 9.9$ & $\$ 1.5$ & $\$ 11.3$ \\
Nondepository credit intermediation and related activities & $\$ 8.8$ & $\$ 21.8$ & $\$ 30.6$ \\
Management, scientific, and technical consulting services & $\$ 7.6$ & $\$ 4.0$ & $\$ 11.6$ \\
Industries 11 - 20 & $\$ 60.8$ & $\$ 62.9$ & $\$ 123.7$ \\
All other industries & $\$ 259.5$ & $\$ 408.4$ & $\$ 1,762.7 *$ \\
\hline Total & $\$ 454.7$ & $\$ 638.7$ & $\$ 2,188.2$ \\
\hline
\end{tabular}

* Includes direct on-site and off-site employment.

Table 24 shows the corresponding jobs impact on sports and related industries. In this case, the industry with the largest supply chain employment impact is real estate establishments. This industry supports 254 jobs. Promoters of performing arts and sports and agents of public figures supports 191 jobs; motion picture and video industries support 190 jobs, and both employment services and services to buildings and dwellings support more than 100 jobs each.

Table 24: Employment Ranked by the Supply-Chain Industries

\begin{tabular}{|c|c|c|c|}
\hline Industry (number of jobs) & Indirect & Induced & Total \\
\hline Real estate establishments & 254 & 400 & 654 \\
\hline Promoters of performing arts and sports and agents of public figures & 191 & 29 & 219 \\
\hline Motion picture and video industries & 190 & 12 & 202 \\
\hline Employment services & 149 & 87 & 236 \\
\hline Services to buildings and dwellings & 116 & 86 & 202 \\
\hline Management of companies and enterprises & 76 & 24 & 100 \\
\hline Accounting, tax preparation, bookkeeping, and payroll & 74 & 39 & 113 \\
\hline Advertising and related services & 66 & 14 & 79 \\
\hline Management, scientific, and technical consulting services & 61 & 32 & 92 \\
\hline Wholesale trade businesses & 55 & 157 & 212 \\
\hline Industries $11-20$ & 338 & 350 & 688 \\
\hline All other industries & 2,460 & 4,045 & $20,339 *$ \\
\hline Total & 4,028 & 5,274 & 23,136 \\
\hline
\end{tabular}




\section{MAJOR FINDINGS}

Over the past 30 years, the sports industry in Charlotte has emerged from a modest regional entertainment industry to an important economic cluster for the regional economy. Sports in Charlotte is now a big business and it is not just the major professional teams but includes a wide range of minor league and amateur sports. In fact, minor league sports have seen the largest growth in terms of number of teams and events. New minor league teams in baseball (Intimidators, Knights, Crawdads), hockey (Checkers), soccer (Eagles), and football (Speed) have provided a range of affordable entertainment option for Charlotte and the greater Charlotte region.

Special events have also seen rapid growth over the past several years, including bowl games, basketball tournaments, golf tournaments, and a range of motorsports events. The growth of sports in the Charlotte region over the past 30 years has been dramatic and is still increasing, as new events and teams have been developed or announced in just the last few years. In addition, the geographic footprint of the regional sports industry is also increasing beyond just the six-county MSA.

- $\quad$ The direct on-site revenue for all sports and related industries in the Charlotte MSA for 2011 was $\$ 763,808,347$.

- $\quad$ The direct off-site revenue for all sports and related industries in the Charlotte MSA for 2011 was $\$ 331,006,260$.

- $\quad$ The direct on-site and off-site revenue spending for all sports and related industries in the Charlotte MSA for 2011 was $\$ 1,094,814,607$.

- The total on-site revenue for all sports and related industries in the Charlotte MSA for 2011 was $\$ 1,610,783,090$.

- The total off-site revenue for all sports and related industries in the Charlotte MSA for 2011 was $\$ 577,424,549$.

- $\quad$ The combined total revenue for all sports and related industries in the Charlotte MSA for 2011 was $\$ 2,188,207,639$.

- $\quad$ The direct employment impact from on-site activities for all sports and related industries in the Charlotte MSA for 2011 was 8,958 jobs.

- $\quad$ The direct employment impact from off-site activities for all sports and related industries in the Charlotte MSA for 2011 was 4,876 jobs.

- $\quad$ The combined total employment impact for all sports and related industries in the Charlotte MSA for 2011 was 23,136 jobs.

- $\quad$ The industry with the largest supplier chain output for all sports and related industries in the Charlotte MSA for 2011 was real estate establishments, with $\$ 28,964,658$ in annual production.

- $\quad$ The industry with the largest supplier chain employment impact for all sports and related industries in the Charlotte MSA for 2011 was real estate establishments, supporting 254 jobs.

\section{AUTHOR INFORMATION}

John Connaughton joined the UNC Charlotte faculty in 1978. He is the director of the Babson Capital/UNC Charlotte Economic Forecast, which is recognized as the leading source of economic information for North Carolina. Dr. Connaughton has authored economic impact studies that have received widespread attention. He is a past president of The Southern Regional Science Association. E-mail: JEC@ uncc.edu

Dr. Swartz has been a Professor of Economics in the Belk College of Business at UNC Charlotte for eight years, teaching undergraduate and MBA students economics and entrepreneurship. She earned the $\mathrm{PhD}$ at Duke University in 1979 and has held teaching positions at the University of Notre Dame and Emory University. In addition to her academic credentials, Dr. Swartz has over 20 years of industry experience having worked for BellSouth International, Motorola, Chicago Public Radio, and a communications start-up. E-mail: CSwartz1@uncc.edu (Corresponding author) 


\section{REFERENCES}

1. Analysis of Economic Benefits from the Toshiba Classic Champions Tour Golf Tournament Newport Beach, California. (2008, December). Retrieved January 8, 2012 from http://www.toshibaclassic.com/ media/2397/economic\%20report\%202008.pdf

2. Baade, R. (1994, April). Stadiums, professional sports, and economic development: Assessing the reality. The Heartland Institute. Retrieved January 8, 2012 from http://www.cppa.utah.edu/Perspectives/ v2i7_Baadeforpub.pdf

3. Baade, R., \& Matheson V. (2000). High octane? Grading the economic impact of the Daytona 500. Marquette Sports Law Review, 10(2).

4. Coleman, R., Gratton, C., \& Shibli, S. (2006). The economic impact of major sports events: A review of ten events in the UK. The Editorial Board of the Sociological Review. Retrieved January 8, 2012 from http://files.campus.edublogs.org/caledonianblogs.net/dist/d/120/files/2011/02/Gratton.pdf

5. Connaughton, J. E., Madsen, R. A., \& McGregor, R. R. (2008, July). Estimating the economic impact of local cultural organizations. Journal of Business \& Economics Research, 6(7).

6. Decker, C. (2007, November). The impact of the 2007 Cox Classic Golf Tournament on the City of Omaha: Survey results and the impact on the metropolitan economy. Retrieved January 8, 2012 from http://cba.unomaha.edu/defa/urbanpubs/2007Cox\%20ClassicImpact_Final.pdf

7. Greig, M., \& McQuaid, R. (2003, August). The economic impact of a sporting event: A regional approach. Retrieved January 8, 2012, from http://www-sre.wu-wien.ac.at/ersa/ersaconfs/ersa03/cdrom/papers/ 170.pdf

8. Hodges, A., Mulkey, D., \& Stevens, T. (2005, May). Economic impact of the players championship golf tournament at Ponte Vedra Beach, Florida, March 2005. University of Florida, Institute of Food and Agricultural Sciences, Food and Resource Economics Department. Retrieved January 8, 2012 from http://www.fred.ifas.ufl.edu/economic-impact-analysis/pdf/PGA-Players-Championship.pdf.

9. Humphreys, B. R., \& Prokopowicz, S. (2007). Assessing the impact of sports mega-events in transition economies: EURO 2012 in Poland and Ukraine. Int. J. Sport Management and Marketing, 2(5/6). Retrieved January 8, 2012 from http://www.ualberta.ca/ bhumphre/papers/ijsmm_uefa.pdf

10. Lockwood, P. (2011, June). The regional impact of sports. Peoria Magazines. Retrieved January 8, 2012 from http://www.peoriamagazines.com/ibi/2011/jun/regional-impact-sports

11. Rattner, L. (2000, August). Regional impact of Texas Motor Speedway: A simulation. Retrieved January 8, 2012 from http://digital.library.unt.edu/ark:/67531/metadc2610/m1/1/high_res_d/problieu.pdf

12. Robertson, R. The economic impact of sports facilities. The Sports Digest. Retrieved January 8, 2012, from $\mathrm{http}: / /$ thesportdigest.com/archive/article/economic-impact-sports-facilities

13. Shils, E. B. (1985, January). Report to the Philadelphia professional sports consortium on its contribution to the economy of Philadelphia. University of Pennsylvania.

14. The Economic Impact of the Olympic Games. (2004, June). PricewaterhouseCoopers European Economic Outlook. Retrieved January 8, 2012 from http://www.pages.drexel.edu/ rosenl/sports\%20Folder/ Economic\%20Impact\%20of\%20Olympics\%20PWC.pdf 


\section{NOTES}

